\title{
The Analysis of Guantsu's Advanced Economic Ideas
}

\author{
Di Wu ${ }^{1}$ a \\ ${ }^{1}$ Randolph-Macon Academy, VA 22630, The United States of America; \\ a Wudi19991019@163.com
}

Keywords: Law of Demand and Supply; Monopoly Economy; Marketing and Taxes

\begin{abstract}
This article introduces the concepts of law of demand and supply and monopoly economy, an all too familiar ideas to the today's readers. But it had been put forth about 2600 years ago, by Guantsu, a Chinese economist and politician. He lived in a period around 700 BCE in China, otherwise known as the "Spring and Autumn Period." During this period, China was in fact a country of many independent states. Wars were fought constantly among these states. Guantsu was the prime minister of a country called Qi. He played a critical role in strengthening Qi economically and politically by putting in place his economic ideas. As a result of his economic policy, Qi had become the strongest country in China. Specifically, Guantsu recommended that the emperor control certain products in Qi's markets, which is the early model of "monopoly economy." During the wars, food is scarce.

Guantsu suggested that the emperor use the government power to balance demand and supply in Qi's markets. This was the early model of "law of demand and supply." Inspired by Guantsu's novel economic ideas, many great scholars in ancient China came up with similar economic ideas such as marketing and taxes. Li Kui and Yang Yan were among them.
\end{abstract}

\section{Introduction}

China, by the 7th century BC, was in the Spring and Autumn Period of the Eastern Zhou Dynasty (770-255 BC). China was primarily a farming society. Although China at that time claimed to be under the Zhou Dynasty, it was formed, in fact, by many of vassal states. The vassal states constantly wage wars against each other to dominate China, known as the Central Plains. During the Spring and Autumn Period, China evolved from more than one-hundred and seventy vassal states to a little more than ten states.

It was during this period that Guantsu (723 BC - $645 \mathrm{BC})$ started to change the political and economic landscape of China. With a humble background, Guantsu raised to the position of chancellor at the State of Qi, and assisted Duke Huan of Qi to achieve the first period of absolute supremacy over other states. Guantsu was later awarded the royal titles of Zhong Fu, Father Zhong by Duke Huan. 


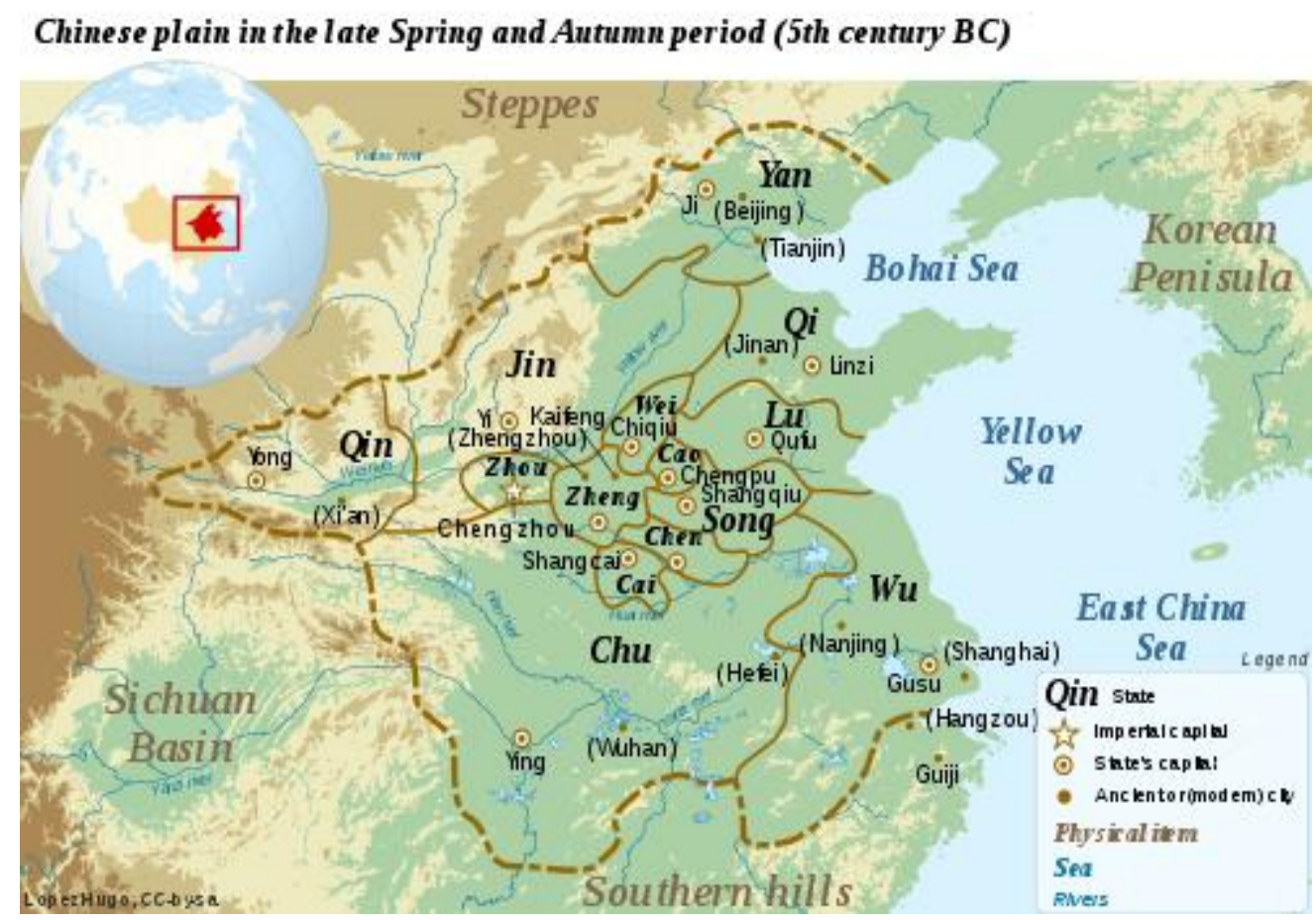

Figure 1. Twelve vassal states in the late Spring and Autumn period

Source: https://en.wikipedia.org/wiki/Spring_and_Autumn_period

As the chancellor of Qi, Guantsu put forth the "district administration" policy, reformed the army, and established the bureaucratic managerial systems [1]. He developed Qi's agriculture, salt industry, and metallurgical industry. Guantsu revolutionized the state's monetary system with his reformative currency making strategies. Guantsu made strategic plans to bankrupt Qi's rivalry states, the State of $\mathrm{Lu}$ and the State of Liang. Guantsu convinced Duke Huan and his officials to wear clothes made of brocade, a fashion that later caught the fancy of commons, which in turn greatly stimulate the clothing industry. Guantsu later banded brocade production in Qi. This ruling has led to Qi's sharp increase of brocade import from Lu and Liang states. Eventually, with Lu and Liang states shifting toward a more brocade export-oriented economy, they chose to forgo their agriculture-based economy, which in the end crashed them financially. It was in the later phase that these two tiny but competitive states were conquered by Qi. Guantsu also offered to use soldiers to make copper coins in exchange for lumber with the State of Lai and the State of Ju with the aim of raising the price of lumber in both states. It was not until the supply of limber surpassed the supply of agricultural products in Lai and Ju that Guantsu ordered Qi's army to attack these two states. The excess of limber resources rendered both Lai and Ju rather fragile in the face of crisis, thus making it possible for Qi's conquering.

Guantsu used similar strategy to handle disputes between Qi and State of Chu. He let Qi's government ministers hoard $60 \%$ of the domestic grain, and then ordered the import of deer skin from Chu, using newly crafted copper coins. This measure had caused high prices for deer skin, thus inducing Chu to abandon their previously advanced farming and hunting industry, rendering its own economy prone to crisis. Without firing a single shot, Qi successfully suppressed $\mathrm{Chu}$, which used to have the largest area and strongest military in the southern region.

In this way, Qi had gained supremacy against other vassal states with the help of Guantsu, and all states that failed to submit to Qi's rule were suppressed one way or others. In the meantime, Qi employed the strategy of "overcoming the rivalries in the name of the Emperor, and controlling the people in the name of the Emperor." Under the influence of the policy put forth by Guantsu, Duke Huan hold 26 confederate conferences in China. Under the supremacy of Qi, all states at the 
conference agreed to jointly assist the emperor, fight against the barbarians, and help the covenants of other small states to reach the realm of unprecedented civilization [1].

According to world history, there are not many civilizations that can develop like this twentyseven hundred years ago. At the time, the economic policies and theories that Guantsu had vigorously implemented not only played a crucial role in Qi's dominance of China, but they also laid a strong foundation for the economic framework of China.

If the modern Chinese economy is like a walking giant, then the economic theory put forward by Guantsu would be the DNA of this giant. With the test of time, Guantsu's economic policy has already been integrated into Chinese economic life.

In the same period, Athens in Europe has just implemented an oligarchic rule. Lydia, a country located in Midwest Asia, had only just begun to mint coins, and the King of Judah knew about the policy of reducing the taxation for his people. The rest of the country did not have a major economic theory, and the powerful Roman Republic was only formed by 509 BC.

But, in China, Guantsu's good policies were implemented at the right time: Qi had ended its own phase of civil war; its people were poor; the state treasury was empty; no workable systems were in place; policies were outdated; the army was ineffective. At this time, Guantsu proposed revolutionary economic policy to save Qi's economy. Within a short period of time, Guantsu reformed the whole nation and helped achieve its prosperity.

This paper will provide an analysis of the two main economic ideas put forward by Guantsu: Law of Demand and Supply; Monopoly Economy.

\section{Using short-term economic means to strengthen Qi's treasury}

Qi's reserve of grains and revenues from salt and iron remained abundant, while its people's demand is insufficient to consume the abundant resources. People wanted to use their skills and labor in exchange for money, but they had to face the state's restriction on food, salt and iron, and currency [1]. With food price very low, people found it hard to find suitable substitutes [2].

Such low food price policy made it easy for the government to keep people's choices under control. People had no other choices but to rely on the monarch. The economy was controlled by the state, and economic policies were made by the monarch. Livelihoods of the people remained largely dependent on the monarch.

The core of such controlling strategy is that the state must firmly control the supply side of the economy, namely controlling food, salt, iron, and currency. The firm grip upon such resources gave the monarch the power to use the "light and heavy" technique to adjust the power and rights distributed to the common people. The state should set up a leveling fund. When the price dropped, the state should buy in; when the price rose, the state should sell out. This would prevent the big entrepreneurs from manipulating the market, which would stabilize the price and enable the country to receive more profits than through normal transactions.

Guantsu also proposed that if the country with the strength of ten thousand-car chariots had a large number of merchants with assets ten thousand pieces of gold; the country that had the strength of thousand-car chariots had a large merchant community with assets of a thousand pieces of gold appeared in the country, which shows that the country's financial resources were lost, and the monarch did not exercise timely control, wealthy businessmen will enter the market and use the hard labor of the people to make profits.

If the monarch did not have a policy to restrict economic circulation, rich merchants would enter the market, so that the financial management policy will be defeated. In addition, price for cloth and all kinds of materials must be regulated. The price of materials should be equal to the value of the 
currency. The grain needed to be priced separately. According to Guantsu, the law of the market had always been that "when food price is high, everything else is cheap; when food price is low, everything else is expensive"[1].

It is obvious that the monopoly by the state on resources was usually imposed on daily necessities, such as salt, iron, grain, etc. Here, it is necessary to mention a notion from a Western economic theory: price elasticity is an index to measure the sensitivity of changes in commodity demand to changes in the price of the commodity itself. The goods that Guantsu advocated for the state to monopolize were commodities that were quite inelastic. For example, no matter how the price of grain fluctuates, the demand would not change much.

It remained the same when it came to salt and iron [2]. Guantsu's policy is the origin of monopoly operation. He suggested that the monarch monopolize people's daily necessities, such as food, salt and iron. This decree could build up the country's finance, strengthen the economy of Qi, control wealthy people's necessities in the hands of the central government, and abolish private business to buy and sell salt and iron.

This policy did not seem to impose additional tax on the people. In fact, it was very clever to obtain huge fiscal revenue. From the perspective of distribution, the monopoly gained all the benefits and the consumers had nothing. This decree effectively eased social contradictions and, at the same time, greatly increased the country's revenue, laying a solid foundation for Qi's hegemony. This policy also worked against private businesses, thus preventing merchants from getting rich.

This policy impacted China's later economic and social development.

\section{Carrying out macroeconomic regulation to maintain a balanced economy}

According to statistics, eating enough food should satisfy people, but people are still hungry. Why? It is because food had been hoarded from being purchased by the commons. According to statistics, coin cast by the monarch was enough for every citizen, but there were still people who never used it. Why? The coins were restricted from entering the market. Therefore, if the monarch could not spread the currency to regulate the people's expenses, even if the agriculture was strengthened and the production was accelerated, endless casting of the coins would only cause inflation, which in turn rendered things less valuable. The reason for this is not difficult to understand. In front of the same resources: land and capital, the resulted income of less calculated and calculated people could be very different. If people are too rich, they don't have strong motivation to make more money. If people are too poor, any punishment will not be powerful enough to make them do otherwise. Laws could not be implemented, and the gap between the rich and the poor would render the governance less authoritative [1].

Guantsu also summed up the rules of the market and proposed a regulatory method. When good price dropped, they could not be sold at half the wage price, decreasing the supply to the market. When the price of a commodity rises, the market price would be rising ten times of the original ones, making people less satisfied. Those who were good at ruling the country would supply the materials when they were insufficient. When merchandises were more than enough, they would buy the goods from market, thus decreasing the market supply. Some people in the private sector were willing to sell at a low price. At this time, the monarch should buy them at a high price. When there was a lack of supply, some people might dare to buy at a high price to inflate the market. At this time, the monarch should sell at a lower price to stabilize the market. This not only made a lot of profit for the government, but also stabilized the price of materials. Such are the practical use of the "light and heavy" techniques. 
The great benefit of the "light and heavy" technique was to purchase low-price goods at a higher price, and then sold them at a lower price. Since the shortage of various materials varied with the season, if there was no adjustment, there would be no shortage, or imbalance between supply and demand, thus leaving room for price to go up. That is, short of supply produced a shortage of market, which in turn increased the demand, thus increasing the supply. The price had to rise until the time when supply and demand reached equilibrium[2].

The monarch knew this truth and left enough food for the cities of a certain population. Spring was the time for ploughing, and summer for sowing. All farm tools, seeds, and food were directly supplied by the state, so rich merchants cannot take advantage of the people. This would ensure best use of resources, and the country will not lose its financial resources to the private sector.

Here, Guantsu's idea coincides with the law of supply and demand, that is, the price of any kind of item will be adjusted spontaneously, so that the supply and demand of the items are balanced to achieve equilibrium of the market. This amount of item that the buyer is willing and able to purchase is exactly the same as the amount the seller is willing and able to sell [2].

In this article, the "light and heavy" technique refers to the state control of commodity circulation and social economic contents, using the "light and heavy" theory to control the circulation of goods, including price balance, and currency rectification, a set of highly centralized economic management models, similar to the planned economy. Constant price does not exist, because if the price does not change, the circulation cannot be adjusted. Only when the price fluctuates can the price law exert its independent adjustment function, and will the commodity be in normal circulation.

As stated above, the Guantsu has repeatedly proposed measures to stabilize prices. "People have a lot of time to buy, and people sell it when they want to." This has stabilized prices and made the country profitable. Secondly, the regulation of currency cannot be relaxed at any time, and money is the main tool for controlling the economy. The Guantsu also advocated the flexibility of foreign trade to take measures to ensure that the things that were lacking in the country did not get exported, to maintain high prices of important materials, and that the useful materials in the world would flow into China.

With remaining resources, one should adopt a low-price policy to promote export. Under normal circumstances, it is best to maintain price equilibrium.

\section{Conclusion}

Shang Yang, a famous reformer in China during the Warring States period (475 BC - 221 BC) once said: kings are needed to rule when three generations pass without clear rules. In the ancient feudal farming society of the Spring and Autumn Period and the Warring States, most of the masters of the real powers believed that the real way to make their empire strong was to follow the laws, policies and traditions left by the ancestors in the glory days. They were afraid of the unknown and influence resulted from changes. But in fact, blindly obeying the old policies and the legal system can only weaken the country gradually; and if it does not make timely changes, there will be the danger of destroying the country.

The thought put forward by Guantsu was at the forefront of the time and was not tested before his time. The first idea he proposed was to use the commodity prices elasticity to monopolize some extremely low-elastic commodities, thereby strengthening national treasury and restricting large businessmen from stealing national resources. Another idea he proposed was to use the fluctuation of market prices and use policies. Or manually manipulate buying and selling to achieve market balance to achieve market balance, which coincides with the theory of elasticity, supply and demand, and monopoly in modern economic principles. 
During the Warring States period, Li Kui of Wei State also proposed that the price be determined by the relationship between supply and demand. The impact price could not be achieved by setting the upper and lower limits of the price. Instead, it needed to be intervened by the government to intervene in supply and demand, and the economic policy must be people-oriented and need to calculate the living of the residents.

Yang Yan, prime minister of the Tang Dynasty (618 AD - 907 AD), the most famous financial reformer in the Tang Dynasty, he proposed the financial concept of "income measuring and controlling," emphasizing that social stratification should be centered around the difference of people's daily demand. As the taxation basis of the two-tax law, the abandonment of the rents during the Tang Dynasty, which was originally based on the standard of government officials, was used to levy the wealth of the land and the industry. It weakened the feudal personal dependency and adapted to the needs of social and economic development at that time. The two-tax law of taxation and taxation replaces the system of taxation and taxation since the Western Jin Dynasty (265 AD - 316 AD).

It is an epoch-making measure and a major breakthrough in the history of Chinese fiscal thought. The two-tax law also adopts the principle of taxation by money. Except for grain, it was paid according to the calculation of the currency in the field, reflecting the development of the monetary economy in the middle of the Tang Dynasty. The two-tax law greatly simplifies the tax system, facilitates the collection of taxation, and eliminates the nuisance caused by many tax collectors. It not only increases the state's fiscal revenue, but also reduces the burden on the people. The Western countries did not have the principle of measuring the quantity of income until the end of the 19th century. The financial ideology of China until the modern times was basically within its means. This is because the level of productivity development is not high. In other words, Yang Yan's measures are too advanced and contemporary.

However, Yang Yan was the first to propose this principle in the world. Similar examples are too numerous to mention. This article only scrapes the surface of a rich literature of Guantsu's economic ideas. It is my sincere hope that students of Chinese ancient economic and political ideas find more about Guantsu's contribution to modern economic theories.

\section{References}

[1] Chen C. Selected Works of Guanzi [M]. Haichao Press, 2014.

[2] Mankiw, N. Gregory. Principles of Economics [M]. Beijing University Press, 2015. 